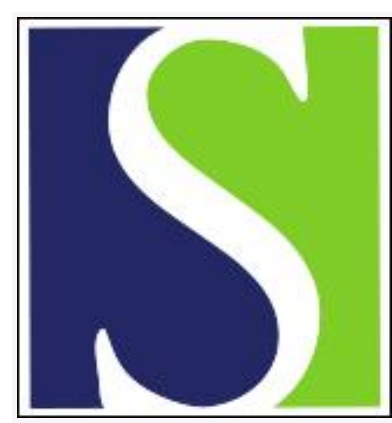

Scand J Work Environ Health 1993;19(3):191-199

https://doi.org/10.5271/sjweh.1482

Issue date: 01 Jun 1993

Iterative use of a priori exposure matrices to improve the characterization of chemical exposures in agricultural work studies.

by Nanni O, Ricci M, Lugaresi C, Amadori D, Falcini F, Buiatti E

Affiliation: Istituto Oncologico Romagnolo (Oncological Institute of Romagna), Italy.

This article in PubMed: www.ncbi.nlm.nih.gov/pubmed/8367697

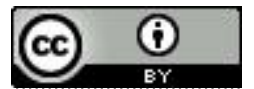




\title{
Iterative use of a priori exposure matrices to improve the characterization of chemical exposures in agricultural work studies
}

\author{
by Oriana Nanni, PhD, ${ }^{1}$ Miranda Ricci, PhD, ${ }^{1}$ Claudio Lugaresi, $\mathrm{PhD},{ }^{2}$ Dino Amadori, MD, ${ }^{3}$ \\ Fabio Falcini, MD ${ }^{3}$ Eva Buiatti, MD ${ }^{4}$
}

\begin{abstract}
NANNI O, RICCI M, LUGARESI C, AMADORI D, FALCINI F, BUIATTI E. Iterative use of a priori exposure matrices to improve the characterization of chemical exposures in agricultural work studies. Scand J Work Environ Health 1993;19:191-9. To assess pesticide exposures of agricultural workers, a priori exposure matrices based on "circumstantial determinants" of pesticide use were incorporated into the questionnaire of a case-referent study. Circumstantial determinants (crops cultivated, their surface areas and crop infestations) were recalled more frequently than specific chemicals. After the matrices were applied, the proportion of missing values fell from 44 to $9 \%$ for specific chemicals, from 97 to $17 \%$ for the dose for each treatment, and from 80 to $16 \%$ for number of treatments per year in a random sample of 40 questionnaires. The number of workers changed from 19 to 30 for parathion use, from 4 to 10 for mancozeb use, and from 4 to 12 for DDT (dichlorodiphenyltrichloroethane) use when the matrix was applied. The matrix enabled exposure levels to be assigned in each case. Provided that the matrix used is valid, this approach could increase the efficiency of case-referent studies on agricultural exposure to chemicals.
\end{abstract}

Key terms: a priori matrices, cumulative exposure assessment, questionnaire.

The definition of exposure to pesticides and of its cumulative dose and period of use among agricultural workers is complicated by the frequent changes of jobs, the variability in type of crops and in crop infestations, the changes in the available pesticides over time, and the subsequent high number and variability of the chemicals used.

As nondifferential misclassification of exposure tends to obscure true etiologic associations, the use of valid instruments for the attribution of cumulative exposure among agricultural workers is crucial in epidemiologic studies. The simplest method for classifying workers by exposure is represented by an analysis based on job titles, some of which are identified as "exposed" per se $(1-3)$. The definition of exposure through this method is expected to produce a high level of misclassification, especially for a job in agriculture, as the use of chemicals is related to the type of crop cultivated and to the crop disease

1 Istituto Oncologico Romagnolo (Oncological Institute of Romagna), Romagna, Italy.

2 Osservatorio Fitopatologico delle Piante (Phytopathology Institute), Cesena, Italy.

3 Divisione di Oncologia Medica (Medical Oncology Unit), Forli, Italy.

4 Unita' di Epidemiologia, Centro per lo Studio e la Prevenzione Oncologica (Epidemiology Unit, Center for Study and Prevention of Cancer), Firenze, Italy.

Reprint requests to: Dr D Amadori, Divisione di Oncologia Medica - Ospedale Pierantoni, via Forlanini 11, I-47100 Forli, Italia. more than to the job, which is usually broad and defined generically.

A second method of defining exposure is represented by the attribution of suspected chemicals frequently used in a specific job to job titles. In this case a priori job-exposure matrices are used to convert the job classification into exposures to chemicals or other agents (4). An a priori matrix is developed when, out of a list of all jobs in a work category and a list of chemicals possibly used, "a priori" exposures are assigned to each job on the basis of available information, and, for each chemical or other agent, the exposed jobs are identified. This procedure permits the job titles to be "transcoded" to specific risk factors. The use of a priori matrices is expected to attribute exposure more efficiently than the use of job titles per se, but it is limited by the difficulties in quantifying cumulative exposures, by the exclusion of unsuspected potential risk factors, and by the underestimation of changes in the job profile over time and among different countries.

These limitations are particularly marked in studies of agriculture, for which job titles are nonspecific and chemical exposures vary as much within as between job categories. A more precise approach is represented by the use of "a posteriori" job-exposure matrices (Siemiatycki method) (5-8). In this case a questionnaire is developed by a group of experts asking information about jobs, specific industries and production, type of materials and machines used, protective equipment, and the like. A team of hygienists then uses the information from a variety of 
sources to attribute the exposure to the responding subjects individually and also to specify the questions with greater accuracy. With this method special emphasis is given to the information gathered from the interviewed subject, and this information is interpreted in terms of exposure on the basis of available data from independent sources. When a posteriori job-exposure matrices are applied, the result strongly depends on the quantity and quality of the information used to define the exposure levels obtained through the questionnaires. As mentioned before, in the case of agricultural work, the questionnaire can refer to job titles alone or can add information on type of cultivated crops by period (9), extension of the cultivated area (10), and protective equipment or other preventive measures used (9). When all of these variables are included in the same questionnaire, the level of complexity and completeness of the information gathered is higher and therefore allows a more precise application of the a posteriori job-exposure matrices. Nevertheless much guesswork is involved in attributing exposure status to the subjects. Questions about time-specific crop diseases and infestations are usually lacking in the questionnaires on occupational history in agriculture; this information could possibly represent the best link between the type of crop cultivated and the use of specific chemicals.

This paper presents the results of exposure assessment for agricultural work within a case-referent study which is now in progress in Forli, Italy, and which has the objective of evaluating the association of pesticide exposure with neoplasms of the hemolymphopoietic system and soft-tissue sarcomas.

To overcome the limited applicability of job-exposure matrices to chemical exposures of agricultural workers and to improve the workers' recall capability, we developed an approach by merging features of both a priori and a posteriori job-exposure matrices and adding indirect, but easily recallable circumstantial evidence of chemical exposure. Exposure was assessed by what we call a priori crop-infestation pesticide-exposure matrices that focus on the link between circumstantial determinants such as cultivated crops, time-specific crop diseases, and infestations and on the quantification of exposure through the determination of the frequency and intensity of chemical use. The matrices were incorporated into the questionnaire to improve recall and were afterwards used again a posteriori to correct the inconsistent answers of the completed questionnaires and to help fill in the "blanks."

\section{Subjects and methods}

A structured questionnaire and 10 crop-infestation pesticide-exposure matrices were incorporated into a population-based case-referent study now in progress at the Medical Oncology Unit and Oncological Institute of Romagna, Italy. In this study the cases were subjects with a hemolymphopoietic neoplasm or soft-tissue sarcoma, and the referents were sampled from the general population. In the population under study a prevalence of agricultural workers of approximately $30 \%$ was expected.

\section{Questionnaire structure}

The cases and referents were interviewed with the use of a questionnaire on agriculture and health with sections on demographic data, dietary and smoking habits, medical history, and occupational history. The section on occupational history was based on structured questions about the lifelong history of all occupations and, for each, all types of jobs done by the subject (11). The answers were then coded with a four-digit code. For those subjects who reported having worked in agriculture, a specific section of the questionnaire was applied, aimed at the identification of exposure to pesticides and at the reconstruction of cumulative exposure.

Ten specific forms, according to type of crop, were developed. Through these forms, questions on the possible crop diseases or infestations were presented, and a specific list of chemicals was applied each time the subject answered positively about one of the crop diseases. For each identified pesticide, and when the use of pesticides was reported but no specific chemicals were identified, the subjects were asked about the usual dose for each treatment and about the number of treatments per year. Each question could be answered with "yes," "no," or "I do not remember."

The list of pesticides was chosen on the basis of both the frequency of use in the area under study and the data available about chronic toxicity in humans. As an example, the form referring to strawberry cultivation is presented in appendix 1 .

\section{Development and use of the matrices}

The matrices were developed by one member (CL) of our team, an expert in phytopathology. A matrix was prepared for each crop mentioned in the questionnaire.

In each matrix one pesticide corresponded to every line and one of the following variables corresponded to each column: kilograms of commercial product used in weight per quintal of water, grams of chemical used per surface unit per treatment, number of treatments per year, period of use. The matrices were developed with the use of information from publications of the National Institute of Statistics reporting amounts of pesticides sold in the area, from catalogues of pesticide producers, from the directory of widely used pesticides in agriculture, and from other local documents (12-14). Experts were requested to define the pesticides used for each disease or infestation, the average amount used per treatment, and the average number of treatments per year. The matrix referring to strawberry cultivation is reported in appendix 2 as an example. 
The subjects were interviewed personally, but the recorded information was often incomplete. In such cases the constructed matrices were applied again to the questionnaires to help complete the lacking information (responses of "I do not remember").

Finally, the matrices were used for correcting some of the answers collected during the interview when they were inconsistent with the matrix itself. The possible inconsistency referred to the date of introduction and subsequent withdrawal of the products. An example of the application of a matrix is given in appendix 3. Information on other variables, such as protection devices, height of the plants, and equipment used for treatment, was collected via the questionnaire and will be used for adjusting the quantitative exposure estimates from the questionnaires after the application of the matrices.

We considered 140 completed questionnaires (cases and referents working in agriculture) indicating a direct use of pesticides in order to evaluate whether the questionnaire and its forms could be used without problems and to quantify the amount of information which could be obtained. On 40 randomly chosen questionnaires (out of the 140) the matrices were then used to help add missing information and correct "impossible" answers. This random sample was considered appropriate and large enough for assessing the value of our exposure estimate method, in view of the fact that the same method had been applied to all of the exposed cases and referents during the analysis of the case-referent study.

\section{Results}

The distribution of the 140 interviewed subjects by gender, age, level of education, number of reported cultivated crops, type of crop, type of job, duration of work in agriculture, and frequency of direct use of pesticides is presented in table 1. Most of the subjects were male, had low or no education, were aged 65 years or more, had been farmers for 35 years or more, and had often or always applied pesticides personally. The more common crops were fruit trees and cereals. The distribution of the same variables was evaluated for a randomly chosen representative subsample of 40 farmers, and no statistically significant difference was found with the chi-square test between the subsample and the total set of 140 questionnaires.

The amount of information obtained through the interview was evaluated for the following variables: type of crop, its surface area, plant diseases or infestations, type of chemicals used, dosage of chemical for each treatment, and number of treatments per year. All of the subjects remembered all of the crops cultivated. The results for the other variables are presented in figure 1.

The variable for which the recall was higher was the type of crop disease or infestation: $76 \%$ of the interviewed subjects remembered the diseases which affected their crops "always," $20 \%$ remembered the diseases "often," and no subject was unable to identify at least some of the diseases. The surface areas of the crops were also frequently remembered. Seventy-three percent recalled the surface areas "always," while only four subjects (3\%) did not remember any of the surface areas. For the other variables, on the other hand, the recall was poor. Only $15 \%$ of the subjects were able to state the use of specific chemicals "always," and $38 \%$ gave answers in the two lower recall categories ("never," "seldom"). Only four subjects (3\%) remembered the amounts of chemicals used "always," while $68 \%$ remembered none of the amounts used. Similar results were ob-

Table 1. Distribution of the 140 agricultural workers who filled out the questionnaire and of those in the randomly selected sample according to their demographic and occupational characteristics.

\begin{tabular}{|c|c|c|}
\hline Characteristic & $\begin{array}{l}\text { All of the } \\
\text { subjects } \\
(\%)\end{array}$ & $\begin{array}{c}\text { Randomly } \\
\text { selected } \\
\text { sample } \\
(\%)\end{array}$ \\
\hline \multicolumn{3}{|l|}{ Gender } \\
\hline $\begin{array}{l}\text { Male } \\
\text { Female }\end{array}$ & $\begin{array}{l}81 \\
19\end{array}$ & $\begin{array}{l}85 \\
15\end{array}$ \\
\hline \multicolumn{3}{|l|}{ Age (years) } \\
\hline $\begin{array}{l}\leq 54 \\
55-64 \\
65-75\end{array}$ & $\begin{array}{l}21 \\
26 \\
53\end{array}$ & $\begin{array}{l}22 \\
25 \\
52\end{array}$ \\
\hline \multicolumn{3}{|l|}{ Education } \\
\hline $\begin{array}{l}\text { None } \\
1-5 \text { years } \\
>5 \text { years }\end{array}$ & $\begin{array}{l}45 \\
41 \\
14\end{array}$ & $\begin{array}{l}37 \\
47 \\
15\end{array}$ \\
\hline \multicolumn{3}{|l|}{$\begin{array}{l}\text { Number of crops } \\
\text { cultivated }\end{array}$} \\
\hline $\begin{array}{l}1-2 \\
3-4 \\
\geq 5\end{array}$ & $\begin{array}{l}19 \\
44 \\
37\end{array}$ & $\begin{array}{l}17 \\
50 \\
32\end{array}$ \\
\hline \multicolumn{3}{|l|}{ Type of cropa } \\
\hline $\begin{array}{l}\text { Cereals } \\
\text { Sugar beet } \\
\text { Grapes } \\
\text { Fruit trees } \\
\text { Strawberries } \\
\text { Vegetables } \\
\text { Seeds }\end{array}$ & $\begin{array}{r}22 \\
14 \\
14 \\
25 \\
10 \\
9 \\
5\end{array}$ & $\begin{array}{r}19 \\
14 \\
13 \\
24 \\
11 \\
13 \\
5\end{array}$ \\
\hline \multicolumn{3}{|l|}{ Job titles } \\
\hline $\begin{array}{l}\text { Share cropper } \\
\text { Farm laborer } \\
\text { Manager } \\
\text { Assistant }\end{array}$ & $\begin{array}{r}89 \\
7 \\
1 \\
4\end{array}$ & $\begin{array}{r}87 \\
5 \\
2 \\
5\end{array}$ \\
\hline \multicolumn{3}{|c|}{$\begin{array}{l}\text { Duration of work } \\
\text { in agriculture (years) }\end{array}$} \\
\hline $\begin{array}{l}\leq 19 \\
20-34 \\
35-49 \\
\geq 50\end{array}$ & $\begin{array}{l}19 \\
21 \\
24 \\
35\end{array}$ & $\begin{array}{l}15 \\
12 \\
37 \\
35\end{array}$ \\
\hline \multicolumn{3}{|l|}{$\begin{array}{l}\text { Direct use of } \\
\text { pesticides }\end{array}$} \\
\hline $\begin{array}{l}\text { Sometimes } \\
\text { Often } \\
\text { Always }\end{array}$ & $\begin{array}{l}26 \\
24 \\
51\end{array}$ & $\begin{array}{l}15 \\
32 \\
52\end{array}$ \\
\hline
\end{tabular}

a Each subject may have been counted more than once. 


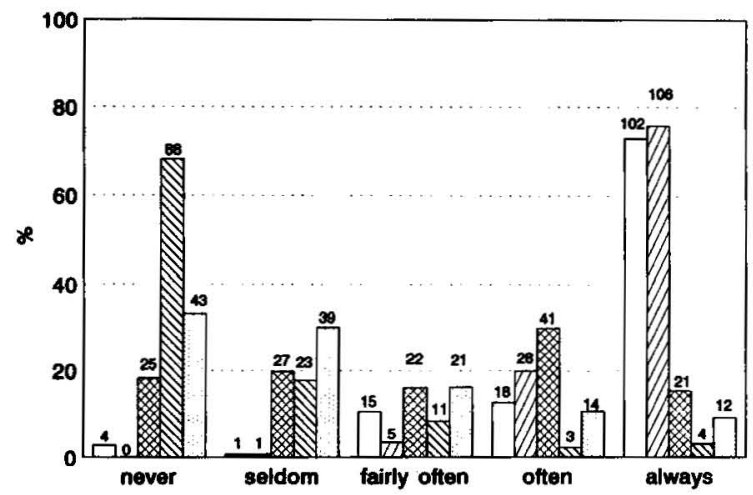

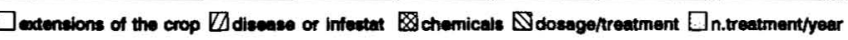

Figure 1. Percentage and absolute number of subjects in the recall categories related to exposure to pesticides in conjunction with the five variables in the questionnaire $(N=140)$ (never = subjects who always answered "I do not remember," seldom = subjects recalling $1-32 \%$ of the information, fairly often $=$ subjects recalling $33-65 \%$ of the information, often $=$ subjects recalling $66-99 \%$ of the information, always $=$ subjects recalling $100 \%$ of the information, infestat = infestation, $n=$ number)

Table 2. Percentage of respondents for which more than $65 \%$ of the data on the exposure variables was available, according to demographic and occupational characteristics of the respondents.

\begin{tabular}{|c|c|c|c|}
\hline \multirow[b]{2}{*}{ Characteristic } & \multicolumn{3}{|c|}{ Percentage of respondents with $65 \%$ of data available } \\
\hline & Chemicals used & $\begin{array}{l}\text { Dose for each } \\
\text { treatment }\end{array}$ & $\begin{array}{l}\text { Number of treat- } \\
\text { ments/year }\end{array}$ \\
\hline \multicolumn{4}{|l|}{ Gender } \\
\hline \multirow[t]{2}{*}{$\begin{array}{l}\text { Male }(N=111) \\
\text { Female }(N=25)\end{array}$} & $\begin{array}{l}50 \\
28\end{array}$ & $\begin{array}{l}7 \\
0\end{array}$ & $\begin{array}{r}24 \\
4\end{array}$ \\
\hline & $X^{2}=3.82 \quad(P=0.05)$ & $X^{2}=0.642 \quad(P=0.42)$ & $X^{2}=3.54 \quad(P=0.06)$ \\
\hline \multicolumn{4}{|l|}{$\begin{array}{l}\text { Duration of work } \\
\text { in agriculture }\end{array}$} \\
\hline \multirow[t]{2}{*}{$\begin{array}{l}<35 \text { years }(N=80) \\
\geq 35 \text { years }(N=56)\end{array}$} & $\begin{array}{l}32 \\
64\end{array}$ & $\begin{array}{l}5 \\
6\end{array}$ & $\begin{array}{l}18 \\
23\end{array}$ \\
\hline & $X^{2}=13.4 \quad(P<0.01)$ & $X^{2}=0.01 \quad(P=0.92)$ & $X^{2}=0.133 \quad(P=0.71)$ \\
\hline \multicolumn{4}{|l|}{ Direct use of pesticides } \\
\hline \multirow[t]{2}{*}{$\begin{array}{l}\text { Sometimes or often }(N=65) \\
\text { Always }(N=71)\end{array}$} & $\begin{array}{l}31 \\
59\end{array}$ & $\begin{array}{l}3 \\
7\end{array}$ & $\begin{array}{l}12 \\
27\end{array}$ \\
\hline & $X^{2}=13.6 \quad(P<0.01)$ & $X^{2}=0.35 \quad(P=0.56)$ & $X^{2}=4.08 \quad(P=0.04)$ \\
\hline
\end{tabular}

Table 3. Positive, negative, and missing responses to the questions on the chemicals used, the dose for each treatment, and the number of treatments per year before and after the use of the matrices. (Number of questionnaires $=40$ )

\begin{tabular}{|c|c|c|c|c|}
\hline & \multicolumn{2}{|c|}{$\begin{array}{l}\text { Before } \\
\text { matrices }\end{array}$} & \multicolumn{2}{|c|}{$\begin{array}{c}\text { After } \\
\text { matrices }\end{array}$} \\
\hline & $\mathbf{N}$ & $\%$ & $\mathbf{N}$ & $\%$ \\
\hline \multicolumn{5}{|l|}{ Chemicals used } \\
\hline $\begin{array}{l}\text { Yes } \\
\text { No } \\
\text { Don't know } \\
\text { Total number of questions }\end{array}$ & $\begin{array}{r}220 \\
819 \\
807 \\
1846\end{array}$ & $\begin{array}{r}11.9 \\
44.4 \\
43.7 \\
100.0\end{array}$ & $\begin{array}{r}454 \\
1229 \\
163 \\
1846\end{array}$ & $\begin{array}{r}24.6 \\
66.6 \\
8.8 \\
100.0\end{array}$ \\
\hline \multicolumn{5}{|l|}{ Dose for each treatment ${ }^{\mathrm{a}}$} \\
\hline $\begin{array}{l}\text { Yes } \\
\text { Don't know } \\
\text { Total number of questions }\end{array}$ & $\begin{array}{r}32 \\
995 \\
1027\end{array}$ & $\begin{array}{r}3.1 \\
96.9 \\
100.0\end{array}$ & $\begin{array}{r}858 \\
169 \\
1027\end{array}$ & $\begin{array}{r}83.5 \\
16.5 \\
100.0\end{array}$ \\
\hline \multicolumn{5}{|l|}{ Number of treatments/yeara } \\
\hline $\begin{array}{l}\text { Yes } \\
\text { Don't know } \\
\text { Total number of questions }\end{array}$ & $\begin{array}{r}204 \\
823 \\
1027\end{array}$ & $\begin{array}{r}19.9 \\
80.1 \\
100.0\end{array}$ & $\begin{array}{r}864 \\
163 \\
1027\end{array}$ & $\begin{array}{r}84.1 \\
15.9 \\
100.0\end{array}$ \\
\hline
\end{tabular}

tained for the number of treatments per year. We then calculated the recall percentages for the same variables according to the worker characteristics presented in table 1 to determine if the worker characteristics were determinants of recall. Female agricultural workers, those who worked for only a short period in agriculture, and those who seldom used pesticides personally showed a worse recall for chemicals, the number of treatments per year, and the dose of chemical for each treatment (table 2 ).

The matrices were then applied a posteriori to the 40 questionnaires in the subsample to complete the missing information and to modify the inconsistent data. The frequency of positive and negative answers and of missing information on the 40 questionnaires is shown in table 3 for the chemicals used, the dose for each treatment, and the number of treatments per year before and after the application of the matrices.

The application of the matrices enabled us to complete 644 of the 807 gaps in the data on chemicals, 660 of the 823 gaps in the data on the number of treatments per year, and 826 of the 995 gaps in the data on dose of chemicals and type of treatment.

A comparison of the distribution of categories with respect to the amount of information obtained before and after the application of the matrices is shown in 


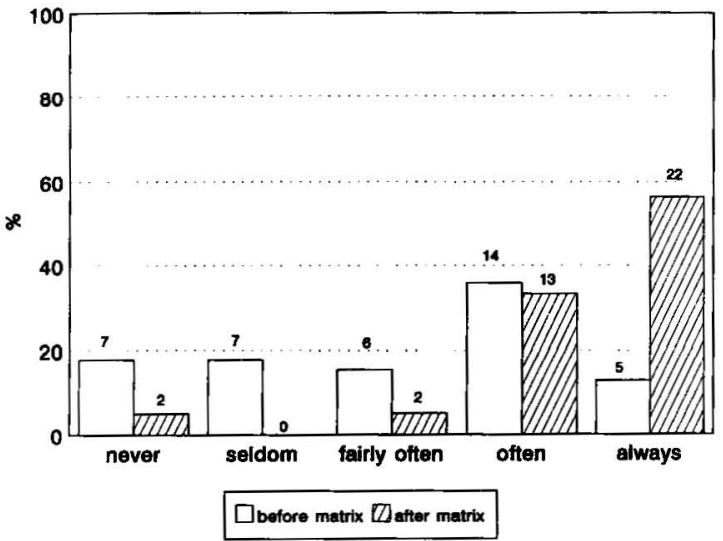

Figure 2. Percentage and absolute number of subjects in the recall categories related to use of chemicals on the questionnaire $(N=40)$ before and after inclusion of the matrices. (never = subjects who always answered "I do not remember," seidom $=$ subjects recalling $1-32 \%$ of the information, fairly often $=$ subjects recalling $33-65 \%$ of the information often $=$ subjects recalling $66-99 \%$ of the information always $=$ subjects recalling $100 \%$ of the information)

figures 2,3 , and 4 for the aforementioned variables. The category of subjects for whom the chemicals used could always be assigned increased from 13 to $56 \%$ after the application of the matrices, while those for whom this information was never available decreased from 18 to $5 \%$. Similar results were obtained for the number of treatments per year. For $56 \%$ of the subjects the dose for each treatment was always available, compared with $3 \%$ before the application of the matrices, while the "never" available category decreased from 72 to $5 \%$.

Although based on small numbers, the effect of the matrices was also evaluated in the 40 questionnaires for each of the demographic and occupational characteristics found to be determinants of recall in the whole set of 140 questionnaires, in order to verify whether the effect of the matrices was limited to specific groups of subjects. The matrices were effective in all of the categories, as the difference of recall percentages before and after the application of the matrices was always statistically significant, except for the number of treatments per year among the women, a finding based on only six questionnaires. The difference was more marked for those with poor recall, the missing information being more frequent; thus the final result was a reduction of the differences in the amount of available information among the various categories of subjects (table 4 ).

Out of the total number of pesticides reported in the 40 randomly selected questionnaires, three were chosen for an estimation of the cumulative dose of exposure before and after the use of the matrices. In table 5 the results are reported for parathion, mancozeb, and DDT (dichlorodiphenyltrichloroethane) according to three steps of attribution of exposure. The first was based on the simple recall of the subject, the second on the application of the matrices for

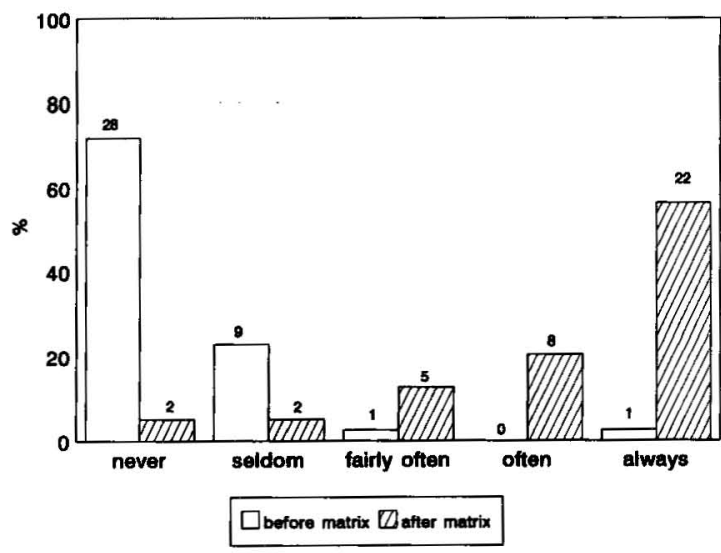

Figure 3. Percentage and absolute number of subjects in the recall categories related to dosage and treatment on the questionnaire $(\mathrm{N}=40)$ before and after inclusion of the matrices. (never = subjects who always answered "I do not remember," seldom $=$ subjects recalling $1-32 \%$ of the information, fairly often = subjects recalling $33-65 \%$ of the in formation, often $=$ subjects recalling $66-99 \%$ of the information, always = subjects recalling $100 \%$ of the information)

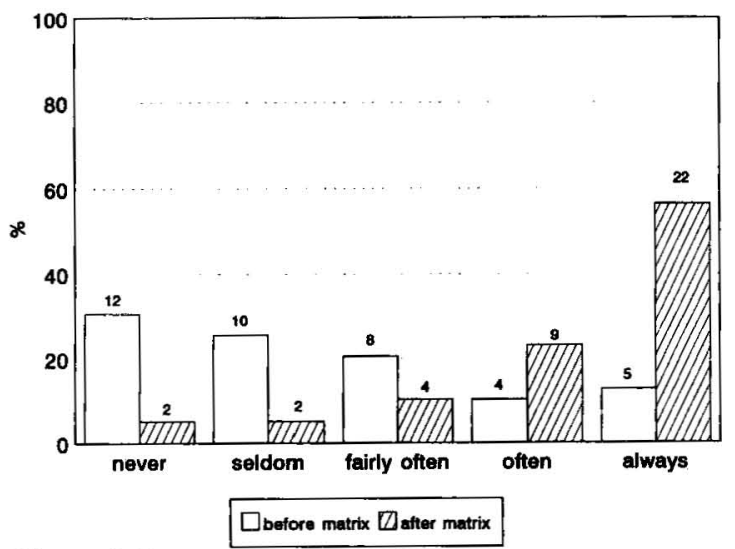

Figure 4. Percentage and absolute number of subjects in the recall categories related to number of treatments per year on the questionnaire $(\mathrm{N}=40)$ before and after inclusion of the matrices. (never = subjects who always answered "I do not remember," seldom $=$ subjects recalling $1-32 \%$ of the information, fairly often $=$ subjects recalling $33-65 \%$ of the information, often = subjects recalling $66-99 \%$ of the information, always = subjects recalling $100 \%$ of the information)

estimating doses when the subject recalled the chemical but not the number of treatments or the dose for each treatment, the third on the application of the matrices also for attributing the chemical when the subject did not identify it. Nineteen subjects reported the use of parathion, only one of whom reported the information necessary for estimating cumulative exposure. In combination with the original information from the questionnaires, we were able to use the matrices to attribute a quantitative estimate of the cumulative exposure for all of the 18 remaining subjects. Furthermore, the full application of the matrices for attributing the missing information on used chemicals assigned parathion exposure to 11 more subjects. 
Table 4. Proportion of information on available exposure before and after the application of the matrices, by variables related to recall among the exposed subjects for which more than $65 \%$ of the data was available.

\begin{tabular}{|c|c|c|c|c|c|c|}
\hline & \multicolumn{2}{|c|}{ Chemicals used } & \multicolumn{2}{|c|}{$\begin{array}{l}\text { Dose for each } \\
\text { treatment }\end{array}$} & \multicolumn{2}{|c|}{$\begin{array}{l}\text { Number of treat- } \\
\text { ments/year }\end{array}$} \\
\hline & $\begin{array}{c}\text { Before } \\
\text { matrices } \\
(\%)\end{array}$ & $\begin{array}{c}\text { After } \\
\text { matrices } \\
(\%)\end{array}$ & $\begin{array}{c}\text { Before } \\
\text { matrices } \\
(\%)\end{array}$ & $\begin{array}{c}\text { After } \\
\text { matrices } \\
(\%)\end{array}$ & $\begin{array}{c}\text { Before } \\
\text { matrices } \\
(\%)\end{array}$ & $\begin{array}{c}\text { After } \\
\text { matrices } \\
(\%)\end{array}$ \\
\hline \multicolumn{7}{|l|}{ Gender } \\
\hline $\begin{array}{l}\text { Male }(\mathrm{N}=33) \\
\text { Female }(\mathrm{N}=6)\end{array}$ & $\begin{array}{l}54 \\
17\end{array}$ & $\begin{array}{l}91 \\
83\end{array}$ & $\begin{array}{l}3 \\
0\end{array}$ & $\begin{array}{l}79 \\
67\end{array}$ & $\begin{array}{l}24 \\
17\end{array}$ & $\begin{array}{l}82 \\
67\end{array}$ \\
\hline \multicolumn{7}{|l|}{$\begin{array}{l}\text { Duration of work } \\
\text { in agriculture }\end{array}$} \\
\hline $\begin{array}{l}<35 \text { years }(N=10) \\
\geq 35 \text { years }(N=29)\end{array}$ & $\begin{array}{l}33 \\
55\end{array}$ & $\begin{array}{l}90 \\
90\end{array}$ & $\begin{array}{l}0 \\
3\end{array}$ & $\begin{array}{l}70 \\
79\end{array}$ & $\begin{array}{l}20 \\
24\end{array}$ & $\begin{array}{l}70 \\
83\end{array}$ \\
\hline \multicolumn{7}{|l|}{ Direct use of pesticides } \\
\hline $\begin{array}{l}\text { Sometimes or often }(\mathrm{N}=18) \\
\text { Always }(\mathrm{N}=21)\end{array}$ & $\begin{array}{l}33 \\
62\end{array}$ & $\begin{array}{l}89 \\
90\end{array}$ & $\begin{array}{l}5 \\
0\end{array}$ & $\begin{array}{l}72 \\
81\end{array}$ & $\begin{array}{l}22 \\
24\end{array}$ & $\begin{array}{l}89 \\
86\end{array}$ \\
\hline
\end{tabular}

Table 5. Estimate of the cumulative exposure to three pesticides before and after the use of the crop-infestation pesticideexposure matrices. (DDT = dichlorodiphenyltrichloroethane, $\mathrm{SE}=$ standard error)

\begin{tabular}{|c|c|c|c|c|c|c|c|c|c|c|c|c|}
\hline & \multicolumn{4}{|c|}{ Parathion } & \multicolumn{4}{|c|}{ Mancozeb } & \multicolumn{4}{|c|}{ DDT } \\
\hline & \multirow{2}{*}{$\begin{array}{l}\text { Number } \\
\text { of } \\
\text { exposed } \\
\text { subjects }\end{array}$} & \multirow{2}{*}{$\begin{array}{c}\text { Number } \\
\text { of } \\
\text { subjects } \\
\text { on which } \\
\text { exposure } \\
\text { was } \\
\text { based }\end{array}$} & \multicolumn{2}{|c|}{$\begin{array}{c}\begin{array}{c}\text { Cumulative } \\
\text { exposure (kg) }\end{array} \\
\end{array}$} & \multirow{2}{*}{$\begin{array}{c}\text { Number } \\
\text { of } \\
\text { exposed } \\
\text { subjects }\end{array}$} & \multirow{2}{*}{$\begin{array}{l}\text { Number } \\
\text { of } \\
\text { subjects } \\
\text { on which } \\
\text { exposure } \\
\text { was } \\
\text { based }\end{array}$} & \multicolumn{2}{|c|}{$\begin{array}{c}\text { Cumulative } \\
\text { exposure (kg) }\end{array}$} & \multirow{2}{*}{$\begin{array}{l}\text { Number } \\
\text { of } \\
\text { exposed } \\
\text { subjects }\end{array}$} & \multirow{2}{*}{$\begin{array}{c}\text { Number } \\
\text { of } \\
\text { subjects } \\
\text { on which } \\
\text { exposure } \\
\text { was } \\
\text { based }\end{array}$} & \multicolumn{2}{|c|}{$\begin{array}{c}\text { Cumulative } \\
\text { exposure (kg) }\end{array}$} \\
\hline & & & Mean & $\mathrm{SE}$ & & & Mean & SE & & & Mean & SE \\
\hline $\begin{array}{l}\text { Before matrices } \\
\text { (step I) }\end{array}$ & 19 & 1 & 126 & . & 4 & 1 & 1209.6 & . & 4 & - & - & . \\
\hline \multicolumn{13}{|l|}{ After matrices } \\
\hline $\begin{array}{l}\text { Step IIb } \\
\text { Step III }\end{array}$ & $\begin{array}{l}19 \\
30\end{array}$ & $\begin{array}{l}18 \\
30\end{array}$ & $\begin{array}{l}74.6 \\
98.9\end{array}$ & $\begin{array}{l}23.5 \\
23.0\end{array}$ & $\begin{array}{r}4 \\
10 \\
\end{array}$ & $\begin{array}{r}3 \\
10\end{array}$ & $\begin{array}{l}240.5 \\
337.2\end{array}$ & $\begin{array}{r}76.7 \\
139.2 \\
\end{array}$ & $\begin{array}{r}4 \\
12\end{array}$ & $\begin{array}{r}4 \\
12\end{array}$ & $\begin{array}{l}40.6 \\
75.9\end{array}$ & $\begin{array}{l}33.3 \\
28.4\end{array}$ \\
\hline
\end{tabular}

a Use of questionnaire alone.

- Application of the matrices when the subjects recalled the chemicals being used

c Application of the matrices for attributing information on chemicals when not recalled by the subject.

Four farmers reported using mancozeb (for one the cumulative exposure could be estimated). The matrix enabled us to assign the dose for each treatment and number of treatments per year in all of the missing cases for mancozeb. The full application of the matrices assigned six more exposures to mancozeb.

For DDT, the application of the matrices increased the number of exposed subjects from 4 to 12 , none of whom had reported the exposure level, and allowed the cumulative exposure to be estimated in all of the cases.

For these three products, the matrices could be used to complete all of the information needed for the quantitative exposures to be estimated. In conclusion, the application of the matrices is expected to have increased the precision of the exposure estimates by having increased the number of observed exposed subjects. It also made an analysis by cumulative exposure levels potentially possible. Finally, seven of the forty randomly selected questionnaires reported at least one period of use of pesticides which was inconsistent with the dates reported in the matrices (difference of more than two years compared with the official date of registration of the product). For these, the matrix was used for correcting the answers.

\section{Discussion}

During a case-referent study on the association of pesticide exposure with hemolymphopoietic neoplasms and soft-tissue sarcomas, an effort was made to improve the attribution of exposure and the quantitative definition of cumulative exposure through the a priori use of crop-infestation pesticide-exposure matrices which were prepared for this purpose.

Ten forms concerning task-related circumstantial determinants were incorporated into a questionnaire completed by farmers; the results showed that it was possible to obtain a good recall of the crops cultivated, the surface areas, and the crop infestations and diseases. However, the forms did not improve the respondents' recall of the specific chemical products used, the number of treatments per year, or dosages, this last information being necessary to estimate cumulative exposure. 
The very poor recall of specific chemical exposure and dosage may be attributable to the nature of the chemical exposures, which are numerous, complex, varied, and probably not frequently known to workers. Although the women seem to have had worse recall than the men, this finding may be a statistical error because of the very small number of women in the sample. Moreover, the female workers had been less continuously and heavily exposed than the male workers, and recall was better among workers with the longest duration and most frequent experience of agricultural work, as shown in table 2.

The use of the forms for identifying cultivated crops and crop infestations permitted the application of the matrices in a representative sample of completed questionnaires, linking this information with the pesticides commonly used for the specific crop diseases in the specific reported period and with the usual number of treatments per year and the dose for each treatment. With this method, the information gathered from the questionnaires was fully used for applying matrices that were specific for time and crop disease.

As the interviewed subjects were unable, in many cases, to remember whether they had used specific chemicals or not, the a posteriori application of the matrices enabled us to assign a high number of subjects who were probably exposed to specific risks and overlooked with the questionnaire alone. In a casereferent study, this result is expected to lead to increased statistical power and efficiency. Although with this method some misclassification of unexposed subjects in the group of the exposed cannot be excluded, it is reasonable to assume that this bias is less relevant than the reverse one (misclassification of exposed in the group of unexposed). The assumption is based on the information that crop diseases were always treated with pesticides in the area under study and in the period considered and that treatment protocols were well established, changing predominantly when a new product substituted the previous one on the market. For these reasons, the information used by the experts for attributing exposure by crop disease and by period should be considered reliable. The data collection capability of the questionnaire alone compared with the results obtained with the combined use of the questionnaire and the matrices showed that the questionnaire was able to assign exposure to workers in a proportion which varied depending on the specific chemical considered. The underestimation of exposed subjects without the use of the matrices was therefore presumably selective and introduced a possible bias into the analysis.

Furthermore, with this method, it was possible to attribute a quantitative estimate of cumulative exposure for all of the subjects who spontaneously reported having used specific chemicals, and also for all of those who were assigned as probably exposed through the use of the matrices. This possibility rep- resented further information and an additional way of classifying exposure as compared with the use of the questionnaire alone, even if the specific forms of the questionnaire were comprehensive.

Although this quantitative estimate of cumulative exposure was based on some assumptions, it represented the only one possible for this population because the interviewed subjects were only sporadically able to report the quantitative variables necessary for the estimate.

In conclusion, the proposed method represents a promising contribution to the attribution and quantification of exposure among agricultural workers.

The effect of the possible reduction in the misclassification of exposure and the quantification of cumulative exposure for a large majority of subjects will be evaluated in the full-scale case-referent study comparing the estimates of relative risks obtained through three steps of analysis. The first will be based on the use of the questionnaire alone, the second on the application of the matrices to the original information on pesticides reported by the subjects for estimating cumulative exposure among agricultural workers, and the third on the full application of the matrices for identifying exposed subjects and for attributing a quantitative estimate of cumulative exposure to the subjects.

\section{Acknowledgments}

The authors wish to thank Ms B Branzanti, Ms MG Minelli, and Ms A Giuseppone for the interviews they carried out and, in addition, Ms Branzanti for her contribution to the matrices.

This study was made possible by the financing of the Provincia di Forli (Province of Forli), the Regione Emilia-Romagna (Emilia-Romagna Region), the Istituto Oncologico Romagnolo (Oncological Institute of Romagna) and the Associazione Italiano per la Ricerca sul Cancro (Italian Association for Cancer Research) in Milan.

\section{References}

1. Woods JS, Polissar L, Severson RK, Heuser LS, Kulander BG. Soft-tissue sarcoma and non-Hodgkin's lymphoma in relation to phenoxyherbicide and chlorinated phenol exposure in Western Washington. JNCI 1987;78:899-910.

2. Pearce NE, Smith AH, Howard JK, Sheppard RA, Giles HJ, Teague CA. Non-Hodgkin's lymphoma and exposure to phenoxyherbicides, chlorophenols, fencing work, and meat works employment: a case-control study. Br J Ind Med 1986;43:75-83.

3. Smith AH, Pearce NE, Fisher DO, Giles HJ,Teargue CA, Howard JK, et al. Soft-tissue sarcoma and exposure to phenoxyherbicides and chlorophenols in New Zealand. JNCI 1984;73:1111-7.

4. Hoar SK, Morrison AS, Cole P, Silverman DT. An occupation and exposure linkage system for the study of occupational carcinogenesis. J Occup Med 1980; 22:722-6.

5. Siemiatycki J, Dewar R, Richardson L. Costs and sta- 
tistical power associated with five methods of collecting occupation exposure information for populationbased case-control studies. Am J Epidemiol 1989; $130: 1236-46$.

6. Siemiatycki J, Day NE, Fabry J, Cooper JA. Discovering carcinogens in the occupational environment: a novel epidemiologic approach. JNCI 1981;66:217— 25.

7. Siemiatycki J, Gèrin M, Richardson L, Hubert J, Kemper H. Preliminary report of an exposure-based, casecontrol monitoring system for discovering occupational carcinogens. Teratogen Carcinogen Mutagen 1982; 2:169-77.

8. Siemiatycki J. An epidemiological approach to discovering occupational carcinogens by obtaining better in formation on occupational exposures. In: Harrington MJ, ed. Recent advances in occupational health; vol 2. New York, NY: Churchill-Livingston, 1984:14357.
9. Hoar SK, Blair A, Holmes FF, Boysen C, Robel RJ, Hoover R, et al. Agricultural herbicide use and risk of lymphoma and soft-tissue sarcoma. JAMA 1986;256:1141-7.

10. Wigle DT, Semenciw RM, Wilkins K, Riedel D, Ritter L, Morrison HI, et al. Mortality study of Canadian male farm operators: non-Hodgkin's lymphoma mortality and agricultural practices in Saskatchewan. JNCI 1990;82:575-82.

11. International Labour Office (ILO). International standard classification of occupations. Geneva: ILO 1988.

12. Lugaresi C. Guida alla difesa antiparassitaria delle colture agricole della provincia di Forli. Forli: Regione Emilia Romagna, 1985.

13. Lugaresi $\mathrm{C}$, Lelli $\mathrm{C}$. Prontuario dei più comuni antiparassitari ad uso agricolo. Forli: Notiziario Consorzio Fitosanitario, 1976. (Suppl 3.)

14. Prosperi GM: La legislazione fitosanitaria italiana. Perugia: Regione dell'Umbria, 1981.

\section{Appendix 1}

Form reporting time-specific diseases and infestations, chemicals used, dose for each treatment, and number of treatments per year for strawberry cultivation, as included in the questionnaire

\begin{tabular}{|c|c|c|c|c|c|c|c|c|}
\hline $\begin{array}{l}\text { Crop: } \\
\text { Strawberry }\end{array}$ & $\begin{array}{ll}\text { Hectares } & \text { From } \\
- & \ldots .\end{array}$ & $\begin{array}{l}\text { To } \\
\ldots\end{array}$ & & & & & & \\
\hline $\begin{array}{l}\text { Diseases and } \\
\text { infestations }\end{array}$ & $\begin{array}{l}\text { Chemical or } \\
\text { commercial name }\end{array}$ & No & Yes & $\begin{array}{c}\begin{array}{c}\text { Amount } \\
(\mathrm{kg}) /\end{array} \\
\text { treatment }\end{array}$ & $\begin{array}{l}\text { Number of } \\
\text { treatments/ } \\
\text { year }\end{array}$ & From & To & Notes \\
\hline \multirow{3}{*}{$\begin{array}{l}\text { Aphides, } \\
\text { lepidopter and } \\
\text { other insects }\end{array}$} & ACEPHATE: ortene & - & - & - & - & - & 一 & $\ldots$ \\
\hline & $\begin{array}{l}\text { LINDANE: adorifora, } \\
\text { aficida rumianca, } \\
\text { cyclanol, dorigamma, } \\
\text { emulgamma, exafis, } \\
\text { gamma } 20 \text {, geolingex, } \\
\text { lindaclor, rodan, lindaforte, } \\
\text { lindamul, lintox, lindasol, } \\
\text { lindavis, lingex, terlin, } \\
\text { toxin, verdinal, agrocide }\end{array}$ & - & - & - & - & - & - & $\ldots$ \\
\hline & $\begin{array}{l}\text { TRICLORFON: } \\
\text { dipterex, toxene }\end{array}$ & - & - & - & - & - & - & $\cdots$ \\
\hline \multirow[t]{6}{*}{$\begin{array}{l}\text { Cryptogamic } \\
\text { diseases } \\
\text { (botrytis } \\
\text { cinerea, etc) }\end{array}$} & $\begin{array}{l}\text { TMTDa: fernide, } \\
\text { marisan, nomersan, } \\
\text { pomarsol, temtidin, } \\
\text { thirsol, florene }\end{array}$ & - & - & - & - & - & - & $\cdots$ \\
\hline & $\begin{array}{l}\text { CAPTANO: captan } 50 \text {, } \\
\text { captol, orthocide, } \\
\text { CAP 50, santhane, CT50, } \\
\text { sorene }\end{array}$ & - & - & - & - & - & - & $\ldots$ \\
\hline & $\begin{array}{l}\text { FOLPET: orto phaltan, } \\
\text { dipet, folcarb, orval, } \\
\text { folpetan, foltamin, foltan, } \\
\text { mildin, sanfol, tioftal }\end{array}$ & - & - & - & - & - & - & $\cdots:$ \\
\hline & $\begin{array}{l}\text { FOLPET + CAPTAFOL: } \\
\text { fotapet, mycodifol }\end{array}$ & - & - & - & - & - & - & $\ldots$ \\
\hline & $\begin{array}{l}\text { BENZIMIDAZOLICI: } \\
\text { enovit metil, benlate }\end{array}$ & - & - & - & - & - & - & $\ldots$ \\
\hline & $\begin{array}{l}\text { DICLOFLUANIDE: } \\
\text { euparen }\end{array}$ & - & - & - & - & - & - & $\cdots$ \\
\hline
\end{tabular}

\footnotetext{
a $T M T D=$ tetramethyl thiuram disulfide.
} 


\section{Appendix 2}

Crop-infestation pesticide-exposure matrix for strawberry cultivation

\begin{tabular}{|c|c|c|c|c|c|c|}
\hline $\begin{array}{l}\text { Diseases and } \\
\text { infestations }\end{array}$ & Chemical & $\begin{array}{c}\text { Chemical } \\
(\%)\end{array}$ & $\begin{array}{c}\text { Period of } \\
\text { use }\end{array}$ & $\begin{array}{c}\text { Commercial } \\
\text { product } \\
(\mathrm{g} \cdot \text { quintal } \\
\text { of water) }\end{array}$ & $\begin{array}{l}\text { Chemical } \\
\left(\mathrm{g} \cdot \mathrm{Ha}^{-1}\right)\end{array}$ & $\begin{array}{c}\text { Number of } \\
\text { treatments/ } \\
\text { year }\end{array}$ \\
\hline $\begin{array}{l}\text { Aphides, } \\
\text { lepidopter and } \\
\text { other insects }\end{array}$ & $\begin{array}{l}\text { Acephate } \\
\text { Lindane } \\
\text { Triclorfon }\end{array}$ & $\begin{array}{l}43 \\
25 \\
50\end{array}$ & $\begin{array}{l}74 \\
57-75 \\
68\end{array}$ & $\begin{array}{l}100 \\
120 \\
300\end{array}$ & $\begin{array}{r}430 \\
300 \\
1500\end{array}$ & $\begin{array}{l}2 \\
1 \\
1\end{array}$ \\
\hline $\begin{array}{l}\text { Cryptogamic } \\
\text { diseases } \\
\text { (botrytis } \\
\text { cinerea, etc) }\end{array}$ & $\begin{array}{l}\text { TMTDa }^{\text {Captane }} \\
\text { Cane } \\
\text { Folpet } \\
\text { Folpet + captafol } \\
\text { Thiofanatemetil } \\
\text { Benomyl } \\
\text { Diclofluanide }\end{array}$ & $\begin{array}{l}50 \\
50 \\
50 \\
75 \\
70 \\
50 \\
50\end{array}$ & $\begin{array}{l}65 \\
65 \\
66 \\
72-87 \\
71-75 \\
70-75 \\
66\end{array}$ & $\begin{array}{r}300 \\
300 \\
250 \\
150 \\
100 \\
80 \\
100\end{array}$ & $\begin{array}{r}1500 \\
1500 \\
1250 \\
1100 \\
700 \\
400 \\
500\end{array}$ & $\begin{array}{l}3 \\
3 \\
3 \\
3 \\
2 \\
2 \\
1\end{array}$ \\
\hline
\end{tabular}

a $T M T D=$ tetramethyl thiuran disulfide.

\section{Appendix 3}

\section{Application of the matrix to one agricultural worker's questionnaire}

The job-exposure matrix was applied to a questionnaire of a subject who cultivated strawberries from 1965 to 1988 . In this case, information about the amount of pesticides used per treatment was added and the year in which the use of benlate began was corrected with the use of the matrix because it was inconsistent with the matrix reported in appendix 2. (Benlate was registered in Italy for the first time in 1970.)

\begin{tabular}{|c|c|c|c|c|c|c|c|c|c|}
\hline $\begin{array}{l}\text { Crop: } \\
\text { Strawberry }\end{array}$ & $\begin{array}{l}\text { Hectares } \\
01.00\end{array}$ & $\begin{array}{l}\text { From } \\
65\end{array}$ & $\begin{array}{l}\text { To } \\
88\end{array}$ & & & & & & \\
\hline $\begin{array}{l}\text { Diseases and } \\
\text { infestations }\end{array}$ & $\begin{array}{l}\text { Chemical of } \\
\text { commercial }\end{array}$ & & No & Yes & $\begin{array}{c}\text { Amount } \\
\text { (kg)/ } \\
\text { treatment }\end{array}$ & $\begin{array}{c}\text { Number of } \\
\text { treatments } / \\
\text { year }^{\mathrm{a}}\end{array}$ & From & To & Notes \\
\hline \multirow{3}{*}{$\begin{array}{l}\text { Aphides, } \\
\text { lepidopter and } \\
\text { other insects }\end{array}$} & \multicolumn{2}{|c|}{ ACEPHATE: ortene } & $x$ & - & - & - & - & - & $\ldots$ \\
\hline & \multicolumn{2}{|c|}{$\begin{array}{l}\text { LINDANE: adorifora, } \\
\text { aficida rumianca, } \\
\text { cyclanol, dorigamma, } \\
\text { emulgamma, exafis, } \\
\text { gamma 20, geolingex, } \\
\text { lindaclor, rodan, lindaforte, } \\
\text { lindamul, lintox, lindasol, } \\
\text { lindavis, lingex, terlin, } \\
\text { toxin, verdinal, agrocide }\end{array}$} & $x$ & - & - & - & - & - & $\ldots$ \\
\hline & \multicolumn{2}{|c|}{$\begin{array}{l}\text { TRICLORFON: } \\
\text { dipterex, toxene }\end{array}$} & - & $x$ & $\begin{array}{c}99 \\
(1.5)\end{array}$ & 02 & 69 & 88 & $\cdots$ \\
\hline \multirow[t]{6}{*}{$\begin{array}{l}\text { Cryptogamic } \\
\text { diseases } \\
\text { botrytis } \\
\text { cinerea etc) }\end{array}$} & \multicolumn{2}{|c|}{$\begin{array}{l}\text { TMTDb: fernide, } \\
\text { marisan, nomersan, } \\
\text { pomarsol, temtidin, } \\
\text { thirsol, florene }\end{array}$} & - & $x$ & $\begin{array}{c}99 \\
(1.5)\end{array}$ & 01 & 68 & 88 & $\ldots$ \\
\hline & \multicolumn{2}{|c|}{$\begin{array}{l}\text { CAPTANO: captan } 50 \text {, } \\
\text { captol, orthocide, } \\
\text { CAP } 50 \text {, santhane, CT50, } \\
\text { sorene }\end{array}$} & $x$ & - & - & - & - & - & $\ldots$ \\
\hline & \multicolumn{2}{|c|}{$\begin{array}{l}\text { FOLPET: orto phaltan, } \\
\text { dipet, folcarb, orval, } \\
\text { folpetan, foltamin, foltan, } \\
\text { mildin, sanfol, tioftal }\end{array}$} & $x$ & - & - & - & - & - & $\cdots$ \\
\hline & \multicolumn{2}{|c|}{$\begin{array}{l}\text { FOLPET + CAPTAFOL: } \\
\text { fotapet, mycodifol }\end{array}$} & $x$ & - & - & - & - & - & $\cdots$ \\
\hline & \multicolumn{2}{|c|}{$\begin{array}{l}\text { BENZIMIDAZOLICl: } \\
\text { enovit metil, benlate }\end{array}$} & - & $x$ & $\begin{array}{c}99 \\
(0.4)\end{array}$ & 02 & $\begin{array}{l}65 \\
(70)\end{array}$ & 75 & $\cdots$ \\
\hline & \multicolumn{2}{|c|}{$\begin{array}{l}\text { DICLOFLUANIDE: } \\
\text { euparen }\end{array}$} & $x$ & - & - & - & - & - & $\cdots$ \\
\hline
\end{tabular}

a Values in parentheses calculated according to the criteria explained in appendix 2. ${ }^{\mathrm{C}}$ TMTD $=$ tetramethyl thiuram disulfide.

Received for publication: 22 July 1991 